\title{
Research article: Constraints faced by women in empowering themselves through self help groups (SHGs)
}

\begin{abstract}
Article Chronicle:
Received :

02.02.2016;

Revised :

30.06.2016;

Accepted :

11.07.2016

SUMMARY : The study was conducted in Latur district of Marathwada region of Maharashtra state. Data were collected from 120 women respondents. It negligence by other family members regarding the decision taken about economic development $(73.34 \%$ ), had lack of freedom to take decision for self travelling $(66.66 \%)$, them were facing lack of equal treatment by male family members $(51.66 \%)$, lack of co-operation amongst members of SHG $(38.33 \%)$.

How to cite this article : Dawane, V.T. and Gore-Dhalpe, N.D. (2016). Constraints faced by women in empowering themselves through self help groups (SHGs). Agric. Update, 11(3): 269-272, DOI : 10.15740/HAS/ AU/11.3/269-272.
\end{abstract}

\section{V.T. DAWANE AND N.D. GORE-DHALPE}

KEY Words:

Women, Economic empowerment, SHG, Constraints

\section{V.T. DAWANE}

Department of Extension Education, Shreemant Shivajiraje College of Horticulture, PHALTAN (M.S.) INDIA

Email: vijayaranidawane @ gmail.com

See end of the article for authors' affiliations 